\title{
Intermedia
}

International e-journal

Intermedia International e-Journal, Spring -June - $20174(6)$

DOI NO: 10.21645/intermedia.2017.26 Submit Date: 11.04.2016 Acceptance Date: 15.06.2016

ISSN: $2149-3669$

\section{POLITICAL VIEW OF INFORMATIONALISM: SOCIAL MEDIA AND NETOCRACY}

\section{Enformasyonalizmin Siyasal Görünümü: Sosyal Medya ve Netokrasi}

\author{
Assist Prof, Ayşe Aslı SEZGıN ${ }^{1}$ \\ Osmaniye Korkut Ata University, iiBF, Political Science and Public Administration Department, \\ Osmaniye \\ Assist Prof, Tuğba YOLCU² \\ Osmaniye Korkut Ata University, IiBF, Political Science and Public Administration Department, \\ Osmaniye
}

\begin{abstract}
Internet is the most important source of access to the information needed in the new life environment of the information society. This environment, which is formed by the traditional environment through the internet and is called new environment created by the intense influence of the Internet in the everyday relationships, has given a different perspective to the living order of the individual in society, especially with its interactive structure. This point of view is felt in almost every field of society. Informationalism, with its effects from social, economic life to cultural life, is increasingly becoming a subject for researches. In this study, the change social media, which is evaluated within the concept of informationalism and which represents a new and rich communication environment has made on the concept of democracy, has been evaluated with a critical point of view within the framework of the concept of netocracy.
\end{abstract}

Keywords: Informationalism, internet, new media, democracy, netocracy.

Özet: Enformasyon toplumunun yeni yaşam ortamında, ihtiyaç duyulan bilgiye erişimin en önemli kaynağı internettir. İnternetin yoğun etkisiyle kurulan gündelik ilişkilerde, geleneksel medyanın yine internet vasıtasıyla oluşan ve yeni medya adını alan bu ortam, özellikle etkileşimli yapısıyla, toplum içinde bireyin yaşam düzenine farklı bir bakış açısı kazandırmıştır. Öyle ki, bu bakış açısı toplumun hemen hemen her alanında hissedilmektedir. Sosyal, ekonomik yaşamdan, kültürel yaşamdaki etkilerine kadar enformasyonalizm, giderek daha çok araştırmanın konusu olmaktadır. Bu çalışmada da enformasyonalizm kavramı kapsamında değerlendirilen, yeni ve zengin bir iletişim ortamını temsil eden sosyal medyanın, demokrasi kavramı üzerinde yarattığı değişim, netokrasi kavramı çerçevesinde eleştirel bir bakış açısıyla değerlendirilmiştir.

Anahtar Kelimeler: Enformasyonalizm, internet, yeni medya, demokrasi, netokrasi.

\footnotetext{
1 aaslisezgin@gmail.com

2 tyolcu@osmaniye.edu.tr
} 


\section{Introduction}

Global change and the rise of the Internet have resulted in the beginning of a new era called informationalism. This new period, which can be described as a change based on technology in the social organization, emphasizes the ability of individuals and society to interact with the media in maintaining their work in a healthy way (Inan, et.al.2010).

Mass media and media are indispensable elements of democracy. Media has also been an important channel of information and influence between citizens and their elected representatives. However, an important obstacle to the description of the relationship between the media and the democratic political process is the inadequate depth of research in this field. There are few studies that have a macro and micro perspective explaining the mutual relationship between media and democracy and democratization process. Throughout the 20th century, the media was at the centre of the relationship between the ruler and the ruled in any political regime. The media, especially television, has taken its place in public life as an important channel in reaching political information, mainly due to the spread of literacy in the beginning, and as a result of the subsequent developments in communication technologies (Gunther and Mughan, 2000).

In examining the concept of democracy, which takes on a new dimension in the changing structure of the information society, it is also necessary to talk briefly about the concept of the public sphere that emerges as an important concept in researches in the field of media and democracy. It should be noted that the most influential idea about what the public sphere is, and about the relationship between media, democracy and public sphere was by Jurgen Habermas. Emphasizing the role of the media in particular, Habermas emphasized that the media has an important role for the existence of the public sphere. Habermas argues that the public sphere is a network of information reproduced through communicative action. Public sphere anticipates free press, freedom of speech and assembly, political debate and free participation in decisions (Deane, 2005).

Habermas' view of democratization is linked to the process of political participation, which he sees as an indispensable element of a democratic society's core and personal development. In his book The Structural Transformation of the Public Sphere, Habermas compared the active participatory bourgeois public sphere in liberal democracies with the privatized political spheres in the bureaucratic industrial societies in which the media and elites control the public sphere.

A democratic society must be described as a society, in which the public has awareness in the excessive power of the state and othermajor power sources, and the possible corruption, the media assumes the task of control and balance, and there is the separation of powers (Kellner, 2015).

The media, regarded as a separate source of power in democratic societies, has gained a new look that was shaped by the digital media over time, different from the traditional media.

With the arrival of personal computers and the Internet in the 1980s and then the 1990s, massive changes began to take place in public life. Internet can be considered as an environment with transformative effects on politics and democratization of society due to its features such as its being an interactive structure unlike traditional media, its enabling users to be active as an active and creative tool and its being a platform everyone can reach (Van Dijk, 2012). 
The concept of digital democracy, which has begun to be used as a result of the Internet's influence on politics, can be defined as the field of application and research of democracy used in online and offline political communication (Van Dijk, 2012).

We can say that the most important factor in the emergence and implementation of digital democracy is the new media environment that the internet offers and social media networks depending on it. In recent years, through social media, there have been many examples of democratization movements in many different regions of the world. We can see that many resources defend that Internet users, who can make their voice heard in the social media networks created by users and perform political participation most efficiently, are seen as important examples of democracy in digital environment.

In this study, referring to the use of information as a means to create and sustain capitalist power in the information society, with a critical point of view and with the help of approaches to informationalism (Ampuja and Kovisto, 2014). It is also emphasized that there are answers to questions about the concept of netocracy that emerged as a new dimension of democracy and how and by whom democracy is applied in this new digital environment as well.

The fact that especially participation element in democracy is gaining a different dimension with new communication technologies is among the topics discussed. It is emphasized that this dimension causes a change at the instrumental level, and in fact the crisis seen in the participation element in democratic system continues in a different dimension. In this respect, it will be examined in this study whether information society has made progress in the democratic system, or whether the dilemmas of the democratic system are continuing with some instrumental changes rather than any improvement.

\section{Informationalism}

It will not be wrong to state that we are living in a new society structure where information is the main source of power today, with the influence of the developments in communication technologies. In this new society, which takes the place of industrial society, having information and using this information properly is an important factor. Before explaining the concept of informationalism, it should be briefly mentioned about Castells' concept of network society which set the ground for the emergence of information society and the characteristics to be emphasized about information society.

While explaining the concept of the network society, Castells refers to the convergence of three independent historical processes: The social and cultural movements that started in the late 1960s and continued in the 1970s (such as feminism and environmental movements), the Revolution of Information Technologies, which emerged as a paradigm in the 1970s, and the process of restructuring capitalism in the 1980s. Following these three historical processes, Castells emphasizes that the concepts of the Network Society and the Revolution of Information Technologies are independent of each other, but he also adds that the network society cannot exist without revolution in information technologies (Castells, 1997).

In the information economy of the information society, where the source of productivity is the technology that processes information and information, many countries around the world are in a competitive environment, including the technology management process. In such a society, a very different kind of information is mentioned, and at the point of resolution of problems, dynamism and creativity come to the fore (Castells, 1997). 
While the applications that need to be considered in the development of the information society are grouped under several headings, some of them can be summarized as follows: In the information society, each individual should be able to access communication technologies and internet easily, the use of information technologies to gain a competitive advantage should be increased, and education in development strategies for information age should be considered in a central location (Okediji, 2004).

We can talk about many different challenges that arise in the information age, where there is a growing demand for the use of all kinds of communication technology (Turner, 2002). Information can be defined as an attempt to expand the boundaries of the mind to reach its goals with inputs received from other minds. Information can in fact be regarded as an intellectual capital. In the information society where information is an important source of power, some important topics in the correct use of this source such as safe information, correct information, correct information source, accessibility of information also come to the forefront (Mason, 1986).

In the information society, in the beginning of $21^{\text {st }}$ century, informationalism began to be introduced as a new concept starting to form the material basis of societies and encompassing technological development. Prior to this period, the industrialization process, which emerged in the last quarter of the 20th century after the Industrial Revolution and in which the technologies that energy is produced and distributed by non-natural man-made machines are systematized was being evaluated, today the concept of informationalism that the scientific information and technological innovation are evaluated by a similar structure has come to the fore (Castells, 2004).

With informationalism, industrialization has yet to come to an end, and informationalism has recognized industrialization, energy and related technologies as the fundamental components of the process. Informationalism is a concept of strengthening the capacity of information processing and communication, made possible by technological innovations. The environments in which this revolution is directly represented are computers and digital communication technologies (Castells, 2004).

Distinguishing aspects of information and communication technologies that emerged with informationalism from traditional communication methods can be stated as their properties in terms of volume and speed, their repeatability properties and their interactive structures (Castells, 2004).

In informationalism, which refers to the technological arrangements in the network society, networks that determine the structure of society have had the ability to make decisions and receive feedback in real time as carriers of globalization. Networks are now information networks. Networks that are in an important position in the organization of global society are also influential in the emergence of global social movements (Kökalan Çımrın, 2011).

Increasing amounts of information and the increase of possibilities in the message transmission facilities and alternative media in post-industrial societies are used to explain the concept of informationalism (Beckett, 2006).

Sociological studies on the information society have focused on the spread of new information and communication technologies. With his work on the information society, Daniel Bell stated the industry community is to be surpassed by experts who have become equipped with education and have increasingly demanded skills. 
According to Bell, post-industrial society is organized around information to govern social control, change and innovation. Bell also stressed that science has no ideology in the information society. In the same way, Castells embraces the informationalism approach, which focuses on information production and information processing, and which takes the place of industrial society. According to Castells, power is in the hands of those who program information and communication networks, control and connect them to other networks (Ampuja and Kovisto, 2014).

In the new economic system based on information, the key to development is information. Having a certain level of information in such a society and processing this information which has a critical importance in the production process is a necessity. Information in the information society has an active role in different fields such as economics, social relations, and politics. Network societies seem to have adopted informationalism as a kind of ideology. New communication technologies and the media have played an important role in this existing network system. Political activities are now being done within this digital network and media diversity. While leadership is personalized, the presentation of politics has become differentiated and social issues have begun to be regarded as short-term issues (Çalışkan, 2014).

Mass media, which should be considered as an important resource for the political decisions of individuals, television and newspapers, which are now defined as traditional (Chaffee and Kanihan, 1997) now have a much different appearance in the 21st century. In the acquisition of political information by citizens, in the use of this information in the democratization process, especially new communication technologies have begun to come to the forefront.

In the virtual environment of the new media, there are different opportunities and alternatives offered to different social groups, activists that can affect social change. The concept of information politics, which expresses the demands of information, the ways of specific information content, the forms of representation, the ways of analyzing and changing information, has gained a new dimension through virtual media. This media environment again comes to the forefront while reaching the information, verifying the information reached and representing this information in different forms (Elwood and Leszczynski, 2013). This social environment, especially known as social media and information society, has been a new environment in which a lot of information in different areas, especially political information and movements, is shared.

In the new way of life shaped by technological developments, the forms of communication have changed with the influence of informationalism and the increasing use of new media has led to changes in the concepts of democracy and citizenship (Meriç, 2013).

In the next part of the study, the concepts of democracy and netocracy will be discussed with the same critical point of view before explaining the topic of politics in the new media and social media, depending on the open and controversial nature of informationalism.

\section{Democracy}

In his 1863 Gettysburg Lecture, Lincoln defined democracy as the rule of the people, by the people, and for the people. This generally accepted definition is one of the best definitions of democracy. However, democracy is increasingly becoming a complex structure beyond its simple and familiar definitions. While the concept was used as a purely political definition at first, it is now a general definition used for the system of values. The use of the 
concept of democracy by people from all strata and the belief that it will create a paradise of the earth has made it one of the most haphazardly used concepts (Ringen, 2010). This, in turn, transforms democracy into a difficult concept to define, creating the focal point of the debate.

As there is no agreed definition, approaching the concept of democracy in terms of criteria will be a more healthy method. In this context, Robert A. Dahl sets out five criteria for democracy. These are; Effective participation, equality of vote, acquisition of information, the right to say the last word on the agenda, and the inclusion of adults (Dahl, 2001). According to Schumpeter, who defines these criteria in terms of the process of actualisation, democracy is a political method. It is a type of institutional treaty designed to exist as a political force in both legislative, conduct and decision-making processes (Schumpeter, 1975).

Three basic questions need to be answered in order to better understand the concept in these definitions for democracy (Heywood, 2013):

- Who are the people?

- In what sense will the people rule?

- What are the boundaries of people's rule?

The answer to "Who are the people?" is simple: People refer to all people. In practice, however, every democratic system sometimes limits political participation seriously. Today, even the expansion of voting rights has dragged the discussions on this limitation to a different dimension. People are practically the majority, which is interpreted as the dictatorship of the majority. In the final analysis, when the people are evaluated as the sum of free and equal individuals, it conflicts with majoritarianism and makes it difficult to apply the democratic principles when it is stated that the decisions that everyone agrees on concern people.

The question, "How should the people rule?" brings about a debate on the limits of participation. In addition to the representative democracy, which limits participation to voting, a variety of democracies have emerged that desire more rights than just voting.

The question "What are the boundaries of people's rule?" draws attention to the separation between the public and private spheres. The aim of democracy is to provide a legal framework in which individuals can conduct their own activities through special public participation processes and can follow their special interests.

Although all these criteria are directive in defining democracy, the problem of democracy actually emerges at the point of its implementation. Democracy is quantitatively (in terms of the number of democracies in the world) is powerful but it is qualitatively (in terms of the performance of these democracies) weak (Bernard, 2000). Today, although many countries identify themselves as a democratic system, the situation seems to be different in practice. In this respect, the efforts to establish a democratic system in many countries can in fact be expressed as an effort to legitimize political regimes by taking advantage of the label of democracy.

The surveys conducted by Freedom House, the American freedom organization for the implementation of democracy in terms of the countries, constitutes an important field of research on the graduation of civil liberties and political rights applied to the citizens of the countries. When the results of the researches are evaluated, it is seen that there are deficiencies in terms of implementation in many countries. In particular, it is clear that some countries are under the "electoral democracy". This, too, shows that democracy is still reduced to merely voting. 
Especially in the light of the debate about elections, we can roughly deduct the many theories and definitions about democracy in two options: the classical theory and the elitist theory. All debates are held at the point of whether ideal governance is self-directed governance with the active participation of citizens in decisionmaking or an elite race in which it only approves a certain minority's authority to rule by gathering certain facts about people through elections (Barry, 2012). This situation brings the debate on democratic rights, which is supposed to develop in parallel with technological developments. As technology develops, access to information is becoming easier and progress is being made, especially at the point of political participation. However, there are also opinions stating that this situation creates new political elite.

\subsection{Democracy in the Information Age: Netocracy}

Globalization is one of the fundamental concepts that shape the modern world as a phenomenon that brings about changes in the field of technology as it does in every field. The source of technology of globalization is two different types of revolution, communication and information. The vehicle of the communication revolution is the telephone, and the vehicle of the data processing revolution is the computer. A new technology, communication and information revolution has been born for these two; the telephone and the computer develop together (Kongar, 2001). The most important change and transformation of this revolution has been realized in the field of information. Acquisition, transfer and development of information have undergone a great transformation with technology. The social counterpart of this transformation has become the knowledge society or the information society.

There are different approaches as to what the knowledge society and information society are. The first recognizes the knowledge society as a society that produces information more than it produces products. Second treats the information society as information explosion. The third identifies the information society with communication and information technologies (Irzık, 2002). In addition to this, the new society structure that the internet reveals is described as a network society.

According to Castells, who put forward the concept, the network society that gives priority to information is a new social organization structure driven by information technology, formed in information networks and spread all over the globe. While this structure changes the interaction between people in a cultural sense, it also affects the relations of production, consumption and power of social structure (Castells, 2005a). This new structuring is the recycling of the capitalist economy. With the network society, Castells presents it as a consequence of a series of interaction processes rather than presenting it as a direct result of the emerging information technology revolution. While defining these processes as a complex process such as individual creativity, global economy, and world geopolitics, he presents the areas in which the results become concrete in production, communication, management and lifestyle (Castells, 2005b). According to Castells, the process of creating networks based on the Internet is not only an organization and a device of struggle, but also a new form of social interaction, taking action and decision-making (Castells, 2006).

The change in decision-making ways is directly linked to democracy. This connection is in the form of direct influence of the technological revolution in the participation of democracy. Significant effects can also emerge in the information society in terms of the democratization of the society. However, the impact to increase the participation is shifting to the positive direction as people use the information to control their lives. They use computers to increase the amount and usefulness of information that reaches everyone in participatory economies, contributing to the centralization of the decision-making process. In societies with this type of 
economy, computers can provide rapid communication, enriching cultural and political discourse, and democratizing society in general (Albert and Hahnel, 1994). It is alleged that this situation shakes the balance of power between the ruler and the ruled, making it possible for everyone to enter in a specific environment with the Internet on an equal basis without the limitation of class, race and religion (Cairncross, 1997).

Assuming that the present conditions are realized, it can be assumed that the liberal democracy brings a solution to the crisis of representation, but there are also opposing views. Critics are generally about the executive class. This situation is explained by the idea that the information society is a myth developed to serve the interests of the initiators and the executive group of the information revolution. Mass democracies are constantly in need of surveillance. In the administration of complex societies, surveillance mechanisms in which every kind of infrastructure is prepared by the information technology in terms of holding and managing power, become standard instruments of social control (Kumar, 1997).

In order to be able to explain this situation and to be able to determine democracy's connection with the internet, it is necessary to think about internet users. Internet users will vary according to the level of development and cultural structure of the community. When we look at the profiles of internet users in our age, it can be said that the cultural levels are high, they are well educated and the income levels are above average. This is especially more significant in developing countries. However, if internet using is taken as a criterion, this situation is seen to increase day by day. In this case, the purposes of using the internet as another criterion will come to the agenda. It is also possible to explain this situation depending on the educational and economic conditions, but the culture created in this area is also important. A situation will show up in which Internet usage culture is usually confined to the popular fields, and the internet does not address to the public policy and therefore the public space, but to the private space, especially for the young people.

In this society of the new world order, developments in new communication technologies and in the field of internet have also changed public sphere definitions. Today, when the social relations are moved to the internet environment, the network of relations between the individuals carries contradictions. As the communication network evolves, the individual becomes lonely. In the present day when the validity of face-to-face relations has decreased, the individual is active in the virtual environment and alone in the real environment. Assuming that the interests of the individuals in the virtual environment are determined according to their cultural levels, it will be seen that a certain group of people is interested in the public policies. The end of this situation will be the loss of public life, one of the most important qualities of democracy, or the abandonment of it to a certain group, as public life begins to narrow and become dysfunctional. In short, the view that real democracy will begin through the Internet will remain unrealized utopia, and humanity will face the danger of falling into the claws of totalitarian or elitist regimes (Dolgun, 2004).

With reference to Pareto's saying "History is a cemetery of aristocracies", we can say that the internet has actually created a new ruling elite while lifting the traditional ruling elite. This shows us that a new aristocrat class emerged in the network society. Brad and Söderqvist conceptualized this group as netocrats. According to them, this situation appears to be "a living democracy, but in fact it is a staged show for the masses" (Bard and Söderqvist, 2015). The weight of a certain group in the creation of public policies is incompatible with the basic principles of democracy and especially with the principle of participation. The new model of democracy that emerged in this sense is in fact in front of us with a new appearance that embodies the dilemmas of classical democracy. 
The system that emerges is called netocracy by Brad and Söderqvist. According to them, this system is an inevitable reality. The cost of defying this inevitable reality is the exclusion of the information economy. They pointed out the difficulties of transition to this class by introducing important functions into netocrats they define as the new elite group in the network society. For example, someone in the consumer class will increase his wage only as long as he cooperates with netocrats; but he will not be a netocrat anyway (Bard and Söderqvist, 2015).

They clearly explain this emerging social order with an analogy: "The spectators simply walked out of their seats and left the theatre. The old capitalist was left alone on stage, asking himself why no one listened to his wise words in an increasingly angry manner. Sound coming from the foyer is rising steadily. The audience is now communicating with each other. Some are offering drinks and dance music is rising from the speakers at the corners. Curator, network virtuoso who hosts this unprepared party, is the new big star shining in this dimly-lit nightclub world" In this new social structure they also emphasized the end of the capitalist system. For them, the new age is informationalism. The political order established by the new aristocratic class netocrates in this age is netocracy. Although this system seems like a new political system, it is in fact a critique of democracy towards the failure of the implementation of pure democracy.

\section{A Brief History of Politics}

We can talk about two difficulties in clarifying the meaning of politics among people living in society. The first is the fact that the everyday use of politics brings about a number of connotations. The other is that there is not a consensus on the concept even among respectable authorities.

Conflict is a struggle and a fight. Conflicts arising from differences among people form the basis of politics. This conflict is related to the sharing of material and spiritual values. In another definition, realization of common good is emphasized rather than conflict (Kapani, 2011). However, although these definitions seem to be opposite, they are in fact complementary descriptions. Conflicts emerging in the process of sharing material and spiritual values in the social area are in fact a search for common good. In fact, these definitions are two different faces of politics.

Despite these difficulties, definitions are generally reduced to four headings. The first is politics as the art of governing; the second is politics in the sense of public affairs; the third as reconciliation and consensus; and finally the politics as the distribution of power and resources (Heywood, 2013).

As it is seen in the definition of politics, politics, because which contains the human element, is as old as the history of mankind. But politics is, above all, a social activity; it is always a dialogue, never a monologue. Lonely individuals like Robinson Crusoe cannot do politics; politics can emerge only with the arrival of Friday (Heywood, 2013).

Politics comes from police. The meaning of this is the city state in ancient Greece. It is seen from this definition that politics is an old concept that we can take up to the time of Ancient Greece. Aristotle, the founder of the discipline, calls politics the master of all sciences (Roskin and Cord, 2015).

Politics has been studied in different branches of science before becoming an independent science. Politics has recently become an independent science. The change in research topics is also influential on political science becoming an independent science. Before being an independent science, politics was a subject to the researches in 
the form of political philosophy. However, with the modern age, political institutions have begun to be investigated and examined. This disorganized image of political science continued after the Second World War. It witnessed new developments with the Second World War and this became its independence manifestation (Kapani, 2011).

\subsection{Politics and Democracy in the New Media}

The new media has given a new dimension to the political arena in ways that are different and diverse from those used by traditional politics. The 2008 US Presidential Election and Obama's success has been the subject of many researches as an important example of the successful use of the internet in electoral campaigns. This campaign has been an example for subsequent campaigns in the sense that citizens directed an election campaign directly and voters were quite active on the web. Blogs, social media networks, video sharing sites provide new ways of ensuring popular interest for politicians, as well as encouraging citizens' participation in the political process (Gibson, 2009).

Towards the end of the 20th century, cable television systems have enabled hundreds of television channels to enter our homes, while satellite connections have increased the range of channels offered for radio and television. Thus, political messages began to be customized to the masses with different characteristics, without cost. Representatives of different groups of religious beliefs or sexual orientation, different professional groups were able to access messages that offer solutions to specific problems that concern them through these traditional media tools (Graber, 1996). Following this new approach of message transmission, the internet has introduced a much wider area to its message source.

The first move towards Internet-based digital democracy has been at the point of producing large-scale virtual public spheres. It is stated that in this environment provided by information and communication technologies between citizens and politicians, open and equal information sharing is supported to support democratization. However, as a result of this development, some prejudices and factionalism about the internet and its applications started to be mentioned and experts who make researches in the cultural field also pointed out that Habermas' views on the public sphere were heavily influenced by these new virtual environments. It is argued that this new environment allows for a rational style of communication that promotes democracy, while at the same time keeping those who hold economic power in the forefront compared with other social identities (Loader and Mercea, 2011).

Despite this criticism towards digital democracy, social media platforms (Twitter, Facebook, YouTube etc.) emerged after a new technological wave. This second generation (Web 2.0) application of presentation of democracy on the Internet links the public sphere model and the special area of autonomous political identity to a large number of different political spheres with a citizen-centred perspective. It is therefore argued that we have moved out of the earlier confined space to a new field where rational thinking is possible (Loader and Mercea, 2011).

Since the 1990s, discussions about the use of social media in internet activism and political social movements have been increasing in order to evaluate the contribution of internet and social media to politics, and to democracy. In digital activism, which began to increase in the late 1990s, the internet became an important tool used to react to the excesses of neoliberalism and the transnational position of capitalism. Social movements have become international in time, and the concepts of globalization politics, democracy and social justice have been frequently discussed in this digital environment. The Internet has begun to be viewed as an important tool used to 
support the anti-war / anti-peace, social justice movement globally in this period of heightened terrorism and intense political struggles (Kahn and Kellner, 2004).

In addition to the traditional media, the use of the new media to create a new public sphere and to implement democracy in the electronic environment has also changed the political communication activities. The Internet represents the transition from mass media to interactive media and from monological communication to the new communication process of active dialogue and significantly increases participation opportunities. In addition, the internet and new media have also caused the news industry and journalism profession to struggle to survive. It is argued that the new media weakened the traditional mediation function of journalism. The majority of information circulating on the Internet is not produced by journalists or news media. Political actors can now transmit their messages directly to the public without resorting to traditional news channels (Mazzoleni and Schulz, 1999).

\subsection{Critique of Democracy in Social Media}

After the Arab Spring, that broke out in Tunisia and Egypt in early 2011, researchers tried to understand the political change movements that internet and social media created in authoritarian regimes. These studies can be evaluated in different perspectives. As well as those who see the Internet in an effective role in the collapse of authoritarian regimes, it is also possible to talk about a different point of view that suggests that the Internet could be a force supporting these regimes (Tüfekçi and Wilson, 2012).

Digital media and news distribution happening through new media have also strengthened the continuity of ideological sharing through information sharing. Protests and revolutions have influenced the world agenda in recent years, which brought the role of social media to the forefront. Compared to the existing traditional viewpoint, social media makes it easier to organize and implement regime change (Loader and Mercea, 2011).

It is an important factor for the societies to produce, use and access information in determining their political and economic situations. Information in the age of information has an active role in every field, especially the economy. Leadership has become personalized in this age and the presentation of politics has also been differentiated. Today, social movements and social changes cannot be understood without considering the social, political consequences of the age of information and the structure of the Internet (Loader and Mercea, 2011).

Surveys on the Internet, new media and social media have indicated that network-based media has restructured communicative power relations. In particular, it is pointed out that the fact that social media is usercentred hinders the media from being a monopoly, and from being one-way used by state and commercial organizations. According to this view, social media is accessible by many citizens living in technologically, financially and legally developed societies. Individuals surrounded by social media are no longer passive consumers of political party propaganda. The assumption that real resources are involved in the debate (Loader and Mercea, 2011) through different points of view from alternative perspectives is stated to emphasize the influence of social media in the process of political communication.

In social networks, we can see that the connections that represent different interests, contrary to equal distribution, attract the majority of users with the influence of individual preferences. From the point of view of the users, it will be possible to mention the disproportionate authoritarian effect on the sources of information. It will 
be noted through the boundaries of specific mechanisms of search engines that the competition in political discourses is limited (Loader and Mercea, 2011).

The effects of social media, especially in the political arena, are discussed through CyberOptimist and Cyberpessimist approaches. According to Cyberoptimist approach, microblogs allow individuals to challenge the traditional journalism process and directly format media content. It is also possible to communicate interactively with political actors in this environment. According to Cyberpessimist approach, political actors use these new technologies according to their own interests. Moreover, the agenda established is limited by access in a democratic sense. According to Cyberoptimist approach, it is claimed that voters can control the election agenda. On the other hand, according to Cyberpessimist approach, the dominant power in the election process is the candidates themselves. After these approaches, it would not be wrong to say that the idea that new media technologies determine the democratic agenda needs to be reinterpreted from a wider perspective, taking into account the development in all areas of society (Zhao, 2014).

Today, communication and especially social media have the opportunity to be everywhere, causing communication to become artificial and structured rather than a human need. As a result of communication through technology, many industries have been born and developed accordingly. From this point of view, it is possible to see economic-political traces in the background of communication. Thus, it can be said that social media has become an important source of industry (Göker, 2015).

Speed is also an important factor in social media where almost everything has a quantitative value (number of friends, number of followers, number of likes, etc.). In social media, the same, single level and increasingly standardized communication environment has brought communication to a similar position for everyone. The activation of machines has similarized the products by fulfilling human functions in a standard framework. The person who becomes visible in the social media is also included in the monitoring and supervising processes (Göker, 2015). In such a case, the thoughts of the social media liberating the individual will need to be reassessed.

\section{Conclusion}

Nets that surround society are now information networks. The world now has a new social structure. Network societies are emerging. This great transformation in the social area has also had a great impact on the political area. In the process of acquiring, distributing and interpreting information, the Internet presents itself as the most important and even single resource. The seemingly simple and easily obtainable information has brought with it a complicated structure.

In social organizations, the social media tools provided by the internet turned the actual structures into virtual ones. In this new social media and communication environment, communication has become a two-way structure from a one-way feature and interaction has increased. When we take this to the political arena, the result will be that seemingly political participation opportunities become fast and effective. However, the problem lies in the source of information occurring in this area of interaction. Those who point out that capitalist mode of production changed shape in the age of informationalism believe that the source of information is gathered in certain power groups creating new political elite. 
In the political area shaped in the new order, information is shaped in the hands of a certain group of people that produces it. This group is a virtual aristocratic class, with the power of directing people and the political area in the background. Dangers of a system that can quickly and easily spread to every area like the internet will be fast and powerful in the democratic field. In this case, it is also thought that while the political order is passing through a seemingly democratic participatory structure, it may actually be under control by certain power groups.

This area conceptualized as netocracy is portrayed as "the host of a glittering and dazzling party" with the understanding that new communication technologies are driving democracy towards a positive direction. Those who create this new field are the netocrats, that is, the power groups that hold and shape the network power. Although it may seem like a conspiracy theory at first, it is also clear how powerful those who hold the network in the networking societies will be to shape and construct this network.

Netocracy and the creators of this field have also introduced a new field of study for academic studies. However, this concept, unlike democracy, has the power to make unity unlike participatory work. Societies that have begun to live in a new structure within the network system can remain passive without shaping this system. In this environment where bi-directional communication is emphasized, it is necessary to make a broader assessment and the system needs to be questioned.

In conclusion, it would be best to evaluate the new communication technologies emerging from the Technology and Information Revolution as the two sides of a coin: On one side, rising system of values; elements that can create a democratic political atmosphere such as two-way communication, participation, diversity in political behaviour, increase in political consciousness; on the other side, the new power groups of the age of informationalism who control this system of values.

\section{References}

Albert, M. \& Hahnel, R. (1994). Geleceğe Bakmak, 21. Yüzyıl İçin Katılımcı Ekonomi [Looking to Future, Participant Economy for 21st Century] (Çev.O. Akınbay), İstanbul: Ayrıntı Yayınevi.

Ampuja, M. \& Kovisto, J. (2014). From 'Post-Industrial' To 'Network Society' And Beyond: The Political Conjunctures and Current Crisis of Information Society Theory. Journal for a Global Sustainable Information Society, 12, 2, 447-463.

Bard, A. \& Söderqvist, J. (2015). Netokratlar: Fütürika Üçlemesi I [Netocrats: Futuristic Trilogy I] (Çev.G.E. Yılmaz), İzmir: Karakalem Kitabevi Yayınları.

Barry, N. (2012). Modern Siyaset Teorisi [Modern Politics Theory] (Çev. Mustafa Erdoğan ve Yusuf Şahin), Ankara: Liberte Yayınları.

Beckett, R. (2006). Illetişim Etiği ve Enformasyon: Küresel Dünyanın Vatandaşları Kendileri Için Düşünüyorlar [Communication Ethics and Information: Citizens of the Global World Think for Themselves] iletişim Kuram ve Araştırmaları Dergisi, 23, 117-134.

Bernard, C. (2000). In Defence of Politics, 5th Edition, Continuum Pub.

Cairncross, F. (1997). The Death of Distance: How the Communications Revolution is Changing Our Lives, London: Orion Business Book.

Castells, M. (1997). An Introduction to The Information Age. City, 2, 7,6-16.

Castells, M. (2004). Informationalism, Networks, and the Network Society: A Theoretical Blueprint. The Network Society: A Cross-Cultural Perspective, 3-45. 
Castells, M. (2005a). Enformasyonculuk ve Network Toplumu [Knowledge Society or Information Society] Hacker Etiği: İş Hayatına Yıkıcı Bir Yaklaşım, Pekka Himanen, (Çev. Şebnem Kaptan), İstanbul: Ayrıntı Yayınları.

Castells, M. (2005b). Enformasyon Çağı: Ekonomi, Toplum ve Kültür [Information Age: Economy, Society and Culture]. Cilt 1 Ağ Toplumunun Yükselişi, (Çev. Ebru Kılıç), İstanbul: İstanbul Bilgi Üniversitesi Yayınları.

Castells, M. (2006). Enformasyon Çağı II: Ekonomi, Toplum ve Kültür-Kimliğin Gücü [Information Age II: Economy, Society and Culture- Power of Identity] (Çev. Ebru Kılıç), İstanbul: İstanbul Bilgi Üniversitesi Yayınları.

Chaffee, S.H. \& Kanihan, S. F. (1997). Learning About Politics from The Mass Media, Political Communication. Political Communication, 14, 4, 421-430.

Çalışkan, O. (2014). Kamusal Alan Bağlamında Ağ Toplumu ve Yeni Kamusal Alan Arayışı [Searching for a Network Society and New Public Space in the Context of Public Space] Maltepe Üniversitesi Illetişim Fakültesi Dergisi, 1,1, 41-62.

Dahl, R. A. (2001). Demokrasi Üstüne [On Democracy]. (Çev. Betül Kadıoğlu), Phoenix Yayınevi, Ankara.

Deane, J. (2005). Media, Democracy and The Public Sphere. (Edt. Nordicom and CLACSO). Media \& Glocal Change. Rethinking Communication for Development (Part II). Goteborg: Nordicom.

Dolgun, U. (2004). Gözetim Toplumunun Yükselişi: Enformasyon Toplumundan Gözetim Toplumuna [The Rise of the Surveillance Society: From the Information Society to the Surveillance Society], Yönetim Bilimleri Dergisi (Journal of Administration Sciences) 1, 3.

Elwood, S. \&Leszczynski, A. (2013). New Spatial Media, New Knowledge Politics. Transactions, 38, 544-559.

Gibson, R. K. (2009). New Media and The Revitalisation of Politics, Representation, 45, 3, 289-299.

Göker, G. (2015). İletişimin Mcdonaldlaşması: Sosyal Medya Üzerine Bir Inceleme [McDonaldization of Communication: A Review on Social Media] Turkish Studies, 10,2, 389-410.

Graber, D.A. (1996). The 'New' Media and Politics: What Does The Future Hold? Political Science and Politics, 29, 1, 33-36.

Gunther, R. \& Mughan, A. (2000). Democracy and Media: A Comparative Perspective. Cambridge University Press. Heywood, A. (2013). Siyaset [Politics]. (Çev. B.B. Özipek vd). Ankara: Adres Yayınları.

Irzık, G. (2002). Bilgi Toplumu mu, Enformasyon Toplumu mu? [Knowledge Society or Information Society], Günce, Sayı 24.

İnan, E., Tanyeri, E. \& Gölgeli, K. (2010). Küresel Kültürel Ilişkilerin Geleceği: Bulut Kültürü [Future of The Global Cultural Relations: Cloud Culture]. Erciyes Illetişim Dergisi. 1,4. 79-89.

Kahn, R. \& Kellner, D. (2004). New Media and Internet Activism: From The 'Battle of Seattle' to Blogging. New Media Society, 6, 1, 87-95.

Kapani, M. (2011). Politika Bilimine Giriş [Introduction to Political Science] Ankara: Bilgi Yayınları.

Kellner, D. (2013). Habermas, The Public Sphere, and Democracy: A Critical Intervention. (Edt. Lewis Edwin Hahn), Perspectives on Habermas. Open Court.

Kellner, D. (2015). The Media, Democracy, and Spectacle Some Critical Reflections. Cultural Politics, 11, 1, 53-69.

Kökalan Çımrın, F. (2011). Manuel Castells'i Yeniden Okumak: Küresel Ağ Hareketleri Yaklaşiminin Eleştirel Bir Değerlendirmesi [Rereading Manuel Castells: A Critical Assessment of the Global Network Movement Approach] Journal of Social Sciences, 4, 2, 65-77.

Kongar, E. (2001). Küresel Terör ve Türkiye [Global Terror and Turkey] İstanbul: Remzi Kitabevi.

Kumar, K. (1997). Sanayi Sonrası Toplumdan Post-Modern Topluma Çağdaş Dünyanın Yeni Kuramları [Postmodern Society from Post-Industry Society New Theories of Contemporary World] (Çev. Mehmet Küçük), Ankara: Dost Kitabevi.

Loader, B.D. \& Mercea, D. (2011). Networking Democracy? Social Media Innovations in Participatory Politics. Information, Communication and Society. 14, 6, 757-769. 
Loader, B.D. \& Mercea, D. (2011). Networking Democracy? Information, Communication \& Society, 14, 6, 757-769.

Mason, R.O. (1986). Four Ethical Issues of The Information Age. MIS Quarterly, 10,1, 5-12.

Mazzoleni, G. \& Schulz, W. (1999). "Mediatization" of Politics: A Challenge for Democracy? Political Communication, 16,3, 247-261.

Meriç, Ö. (2013). Yeni Medya ve Dijital Demokrasi: Siyasal Yasamdaki Görünümleri Olarak ABD Örnegi [New Media and Digital Democracy: Political Perspectives on Life USA Examples]. Siyasal Iletisim Demokrasi ve Yeni Süreçler Sempozyumu, 97-112.

Okediji, R. L. (2004). Development in The Information Age. ICTSD and UNCTAD, Issue Paper, 9, 58.

Ringen, S. (2010). Demokrasi Neye Yarar? Özgürlük ve Ahlaki Yönetim Üzerine [What Does Democracy Benefit? On Freedom and Moral Management] (Çev. N. Elhüseyni), İstanbul: YKY.

Roskin, M. \& Cord, R. (2015). Siyaset Bilimi: Bir Giriş Political Science: An Introduction] (Çev.Atilla Yayla) Ankara: Adres Yayınları.

Schumpeter, J. (1975). Capitalism, Socialism and Democracy, New York: Harper.

Turner, J. (2002). New Directions in Communications or Which Way to The Information Age? IEEE Communications Magazine $50^{\text {th }}$ Anniversary Commemorative Issue, 24, 10, 50-57.

Tüfekçi Z. \& Wilson, C. (2012). Social Media and The Decision to Participate in Political Protest: Observations from Tahrir Square. Journal of Communication, 62, 363-379.

Van Dijk, J. A. G. M. (2012). Digital Democracy: Vision and Reality. Innovation and the Public Sector, 19, 49-62.

Zhao, Y. (2014). New Media and Democracy: 3 Competing Visions from Cyber-Optimism And Cyber-Pessimism. Journal of Political Science, 2,1. 